\title{
Effect of zinc deficiency on the pregnant ewe and developing foetus
}

\author{
BY DAVID G. MASTERS AND R. J. MOIR \\ Department of Animal Science and Production, University of Western Australia, \\ Nedlands, Western Australia 6009, Australia
}

(Received 10 June 1982 - Accepted 18 November 1982)

\footnotetext{
1. Mature Merino ewes were given either a low-zinc diet ( $4 \mathrm{mg} / \mathrm{kg}$ ) or an adequate- $\mathrm{Zn}$ diet ( $50 \mathrm{mg} / \mathrm{kg})$ for all or part of pregnancy.

2. The ewes consuming the low- $\mathrm{Zn}$ diet consumed $25 \%$ less feed than those given the adequate- $\mathrm{Zn}$ diet during the last $115 \mathrm{~d}$ of pregnancy.

3. $\mathrm{Zn}$ concentration in the plasma of $\mathrm{Zn}$-deficient pregnant ewes declined from 0.7 to $0.3 \mathrm{mg} / \mathrm{l}$.

4. The lambs born to $\mathrm{Zn}$-deficient ewes weighed less and had reduced concentrations of $\mathrm{Zn}$ or less total $\mathrm{Zn}$, or both, in the whole carcass, liver and pancreas.

5. A reduction in activity of alkaline phosphatase $(E C 3.1 .3 .1)$ in the liver and a slight reduction in thymidine kinase (EC 2.7.1.21) activity in the thymus was also observed in $\mathrm{Zn}$-deficient lambs.

6. The Zn-deficient ewes deposited approximately $63 \mathrm{mg} \mathrm{Zn}$ into each single-born lamb; this indicates that during the last third of pregnancy the developing foetuses were accumulating the equivalent of $35 \%$ of the total dietary $\mathrm{Zn}$ intake of the ewes.
}

Severe zinc deficiency affects reproduction in many animal species (see Underwood, 1977). In pregnant rats foetal death, congenital malformations, dystocia, reduced litter size and poor post-natal survival result (Hurley \& Swenerton, 1966; Apgar, 1968; Williams et al. 1973). Little information is available on the $\mathrm{Zn}$ requirements of the pregnant ruminant. Masters (1981) reported that a marginal $\mathrm{Zn}$ intake $(9 \mathrm{mg} \mathrm{Zn} / \mathrm{kg})$ throughout pregnancy in ewes had no effect on the maintenance of pregnancy or birth weights of lambs, although it resulted in large decreases in $\mathrm{Zn}$ concentrations in certain lamb tissues. Apgar and co-workers (Apgar \& Travis, 1979; Apgar et al. 1981) induced $\mathrm{Zn}$ deficiency in pregnant ewes during the last third of pregnancy. Even though the deficient ewes showed a rapid deterioration in condition the number and weight of lambs born were not affected.

The pregnant ewe has an increased requirement for $\mathrm{Zn}$ towards the end of pregnancy. The developing foetus accumulates $1 \cdot 0-2 \cdot 0 \mathrm{mg} \mathrm{Zn} / \mathrm{d}$ near term (Hansard \& Mohammed 1968; Williams et al. 1978). If the increased $\mathrm{Zn}$ requirement during pregnancy must come directly from recently consumed feed and none is contributed from body stores or tissues as occurs in the rat (Hurley \& Swenerton, 1971), then these demands are unlikely to be met when ewes are consuming a marginal or low-Zn diet. Two previous reports have shown that pregnancy results in depletion of $\mathrm{Zn}$ from grazing ewes and that $\mathrm{Zn}$ supplements may increase the number of lambs produced (Egan, 1972; Masters \& Fels, 1980).

The experiment outlined here investigates the effect of $\mathrm{Zn}$ deficiency on mating and pregnancy in the ewe, development of the lamb and accumulation and distribution of $\mathrm{Zn}$ in lamb tissues.

\section{EXPERIMENT AL}

\section{Animals and treatments}

Forty-six mature-age Merino ewes were allocated according to body-weight and plasma $\mathrm{Zn}$ concentrations into two groups of twenty-three. One group was given a $\mathrm{Zn}$-deficient diet containing $4 \mathrm{mg} \mathrm{Zn} / \mathrm{kg}$ dry diet ( $-\mathrm{Zn}$, see Table 1); this concentration was determined by 
Table 1. Dry matter composition of basal diet $(\mathrm{g} / \mathrm{kg})$

\begin{tabular}{lrlr}
\hline \hline & & 10 \\
Hammer-milled wheat straw & $480 \mathrm{NaCl}$ & 10 \\
Wheat starch & 300 & $\mathrm{CaCO}_{3}$ & 25 \\
Sodium caseinate & $\left.44 \mathrm{Ca}_{2} \mathrm{PO}_{4}\right) \cdot \mathrm{H}_{2} \mathrm{O}$ & 25 \\
Urea & $20 \mathrm{MgSO}_{4} \cdot 7 \mathrm{H}_{2} \mathrm{O}$ & 8 \\
Sucrose & $100 \mathrm{KCl}$ & $2 \cdot 3$ \\
& & Trace elements* & $0 \cdot 7$ \\
\hline
\end{tabular}

* Composition of trace element mix $(\mathrm{g} / \mathrm{kg}): \mathrm{Fe}_{2} \mathrm{O}_{3} 50 \cdot 0, \mathrm{CuSO}_{4} \cdot 5 \mathrm{H}_{2} \mathrm{O} 41 \cdot 5, \mathrm{MnSO}_{4} \cdot 4 \mathrm{H}_{2} \mathrm{O} 58 \cdot 0, \mathrm{KI} 1 \cdot 2$, $\mathrm{CoCl}_{2}, 6 \mathrm{H}_{2} \mathrm{O} 5 \cdot 0, \mathrm{Na}_{2} \mathrm{SO}_{4} 836 \cdot 0$, selenious acid $\left(\mathrm{H}_{2} \mathrm{SeO}_{3}\right) 0 \cdot 4, \mathrm{Na}_{2} \mathrm{MoO}_{4} \cdot 2 \mathrm{H}_{2} \mathrm{O} 7 \cdot 9$.

analysis. The other group received the deficient diet supplemented with zinc sulphate to contain approximately $50 \mathrm{mg} \mathrm{Zn} / \mathrm{kg}(+\mathrm{Zn})$; this is considered adequate for growth and maintenance of plasma $\mathrm{Zn}$ levels (Mills et al. 1967). For the first $35 \mathrm{~d}$ the ewes were given up to $0.95 \mathrm{~kg} / \mathrm{d}$, after this they were fed ad lib. The sheep were maintained in two groups in concrete floored pens lined with pressed hardboard; pen floors were washed twice daily. Deionized water was provided ad lib. in stainless-steel troughs and feed in plastic-coated troughs. Every 6 weeks the ewes were dosed orally with $75 \mathrm{mg}$ retinol, $3 \cdot 1 \mathrm{mg}$ cholecalciferol and $87.5 \mathrm{mg} \mathrm{D}-\alpha$-tocopherol.

Oestrus was synchronized using medoxyprogesterone acetate sponges (Repromap; Upjohn Veterinary Products, NSW, Australia). After a minimum of $8 \mathrm{~d}$ on the experimental diets the ewes were allowed to mate naturally with two rams and were then hand-mated to a third. Rams were given a high- $\mathrm{Zn}$ ration daily and were rotated between the groups of ewes every $3 \mathrm{~d}$. Pregnancy status was assessed on the basis of returns to service, plasma progesterone concentrations (see Short, 1972) and laparoscopic examination of the uterus (Sawyer, 1978).

For the final $115 \mathrm{~d}$ of gestation, ten pregnant ewes that conceived during the first oestrus cycle were selected at random from each group. These were transferred to individual metabolism cages made of stainless-steel and high-density polyethylene. The availability of twenty suitable metabolism cages required that not all the ewes to conceive during the first cycle were continued in the experiment. The twenty selected ewes were allocated to the following dietary treatments: (1) $+\mathrm{Zn}+\mathrm{Zn}$, five ewes given the $+\mathrm{Zn}$ diet throughout mating and pregnancy; (2) $+\mathrm{Zn}-\mathrm{Zn}$, five ewes given the $+\mathrm{Zn}$ diet up to day 35 of pregnancy and then the $-\mathrm{Zn}$ diet until parturition (day 150); (3) $-\mathrm{Zn}-\mathrm{Zn}$, five ewes given the $-\mathrm{Zn}$ diet throughout mating and pregnancy; (4), $-\mathrm{Zn}+\mathrm{Zn}$, five ewes given the $-\mathrm{Zn}$ diet up to day 35 of pregnancy and then the $+Z n$ diet until parturition. These treatments allowed comparison of the effects of $\mathrm{Zn}$ deficiency on mating, implantation and early embryonic growth with its effects on later development and growth of the foetus. Day 35 was specifically chosen to re-allocate treatments because at this stage accurate diagnosis of pregnancy could be made by laparoscopic examination.

\section{Measurements and sampling}

Ewes were weighed every 3 weeks and feed intakes were calculated weekly. Plasma was collected weekly, newly grown wool was clipped from the same patches on the mid-side every 8 weeks and colostrum was collected immediately after parturition. Lambs were weighed at birth and then slaughtered by exsanguination before they had sucked. Samples of liver and thymus were removed for thymidine kinase (EC 2.7.1.21) and alkaline phosphatase (EC 3.1.3.1) assays. Whole lamb carcasses and samples of plasma, liver, kidney, thymus and pancreas were stored at $-20^{\circ}$ for later estimation of $\mathrm{Zn}$ content. 


\section{Assays}

Tissue samples were analysed for $\mathbf{Z n}$ by atomic absorption spectrophotometry after lyophilization and wet digestion in nitric acid-sulphuric acid-perchloric acid (10.0:0.5:0.5, by vol.). Lamb carcasses were minced and three 5-g samples were digested and analysed as described previously. Colostrum was similarly digested and analysed.

Thymidine kinase activities were measured by the procedure described by Duncan \& Hurley (1978) with some modifications. Tissue homogenates were prepared as described by Witschi (1970). The reaction mixture in a final volume of 0.6 or $0.525 \mathrm{ml}$ contained:

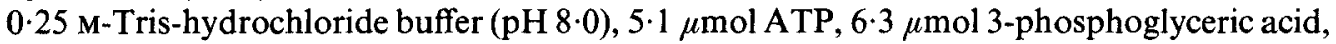
$5.2 \mu \mathrm{mol} \mathrm{MgCl}_{2} .6 \mathrm{H}_{2} \mathrm{O}, 1.6 \mu \mathrm{Ci}$ methyl $\left[{ }^{3} \mathrm{H}\right]$ thymidine $(0.24 \mu \mathrm{mol}, 6.7 \mathrm{Ci} / \mathrm{mmol}$; New England Nuclear, Boston, Mass.) and either $0.1 \mathrm{ml}$ liver supernatant fraction or $0.025 \mathrm{ml}$ thymus supernatant fraction. The mixture was incubated at $37^{\circ}$ for $15 \mathrm{~min}$ and the reaction terminated by spotting $40 \mu \mathrm{l}$ reaction mixture on to a disk ( $20 \mathrm{~mm}$ ) of DEAE cellulose filter paper (Whatman DE81 chromatography paper). The disks were then washed in 1.0 mM-ammonium formate and deionized water, allowed to drain and placed in scintillation vials containing $1.0 \mathrm{ml} 0.1 \mathrm{M}$-hydrochloric acid-0.2 M-potassium chloride. After mixing for $15 \mathrm{~min}, 10 \mathrm{ml}$ scintillant (toluene (technical grade) containing $4 \mathrm{~g}$ PPO and $0.2 \mathrm{~g}$ bis-MBS/ 1 mixed with Triton X-100 (2:1, by vol.)) was added and radioactivity measured using an Isocap 300 liquid-scintillation counter (Searle, High Wycombe, Bucks).

Alkaline phosphatase activity was estimated colorimetrically using sodium $p$-nitrophenylphosphate as substrate. Protein concentration in the tissue supernatant fractions was estimated by the method of Lowry et al. (1951) using bovine serum albumin as the standard.

\section{Statistical analysis}

Comparisons among the four groups of ewes were made using Duncan's multiple range test. Only ewes that continued pregnancy to term and gave birth to live lambs were included in the analysis.

The lambs were grouped according to the final dietary $\mathrm{Zn}$ treatment of the ewe, therefore, lambs from $+\mathrm{Zn}+\mathrm{Zn}$ or $-\mathrm{Zn}+\mathrm{Zn}$ ewes were grouped as high $\mathrm{Zn}$ and those from $-\mathrm{Zn}-\mathrm{Zn}$ and $+\mathrm{Zn}-\mathrm{Zn}$ as low $\mathrm{Zn}$. The two groups were then compared using Student's $t$ test. Logarithmic transformation was applied to sets of values when variances were not homogenous. When the values for twin lambs were significantly different from those of single-born lambs, comparisons between the groups were made using single-born lambs only.

\section{RESULTS}

Fifteen of the twenty ewes maintained pregnancy to term and delivered live young. Two of the ewes given adequate $\mathrm{Zn}(-\mathrm{Zn}+\mathrm{Zn}$ or $+\mathrm{Zn}+\mathrm{Zn})$ required assistance during parturition compared with three $\mathbf{Z n}$-deficient ewes $(+\mathbf{Z n}-\mathrm{Zn}$ or $-\mathrm{Zn}-\mathrm{Zn}$ ). Of the ewes that were not continued in the experiment to term, one resorbed its foetus on approximately day $80-100(-Z n+Z n)$ and three were removed from the experiment or died after refusing to eat (one each from $+\mathrm{Zn}-\mathrm{Zn},-\mathrm{Zn}-\mathrm{Zn},-\mathrm{Zn}+\mathrm{Zn}$ ). A fifth animal was removed due to injury $(+Z n+Z n)$. Two of the animals that refused to eat were found to have large caseous lymphadenitis infections obstructing the oesophagus and trachea.

Ewes given the $\mathrm{Zn}$-supplemented diet throughout pregnancy $(+\mathrm{Zn}+\mathrm{Zn}$ ) had significantly higher feed intakes for the last $115 \mathrm{~d}$ of pregnancy than any of the other groups $(P<0.05)$. These ewes also weighed consistently (though not significantly) more than the sheep in the other groups (Table 2). Plasma $\mathrm{Zn}$ concentrations in the ewes also rapidly responded to dietary $\mathrm{Zn}$ intake (Fig. 1). By the end of the experiment, ewes consuming the low-Zn diet had $30-40 \%$ less $\mathrm{Zn}$ in the plasma than the other groups. Neither wool nor colostrum $\mathrm{Zn}$ concentrations were significantly reduced by $\mathrm{Zn}$ deprivation. 
Table 2. Effect of dietary zinc intake on the pregnant ewe

(Mean values with their standard errors; no. of ewes in parentheses)

\begin{tabular}{|c|c|c|c|c|c|c|c|c|}
\hline \multirow[t]{2}{*}{ Group $^{\dagger} \ldots$} & \multicolumn{2}{|c|}{$+Z n+Z n$} & \multicolumn{2}{|c|}{$-Z n+Z n$} & \multicolumn{2}{|c|}{$-Z n-Z n$} & \multicolumn{2}{|c|}{$+\mathrm{Zn}-\mathrm{Zn}$} \\
\hline & Mean & SE & Mean & SE & Mean & SE & Mean & SE \\
\hline \multicolumn{9}{|l|}{ Food intake $(\mathrm{kg} / \mathrm{d})$} \\
\hline Weeks 5-11 & 0.93 & $0 \cdot 11(4)$ & $0.71^{*}$ & $0.03(3)$ & $0.69^{*}$ & $0.04(4)$ & $0.71^{*}$ & $0.05(4)$ \\
\hline Weeks 12-19 & 0.87 & $0.05(4)$ & $0.59^{* *}$ & $0.03(3)$ & $0.55^{* *}$ & $0.06(4)$ & $0.59^{* *}$ & $0.05(4)$ \\
\hline \multirow{3}{*}{$\begin{array}{l}\text { Live wt }(\mathrm{kg}) \\
\text { Week } 18 \\
\text { Wool } \mathrm{Zn}(\mathrm{mg} / \mathrm{kg}) \\
\text { Week } 20\end{array}$} & & & & & & & & \\
\hline & $44 \cdot 0$ & $0.89(4)$ & $39 \cdot 8$ & $1.09(3)$ & $39 \cdot 6$ & $1.82(4)$ & $41 \cdot 3$ & $1.64(4)$ \\
\hline & $95 \cdot 0$ & $4.4(4)$ & 84.0 & $12 \cdot 2(3)$ & $79 \cdot 0$ & $9 \cdot 0 \quad(4)$ & $87 \cdot 5$ & $10 \cdot 5(4)$ \\
\hline
\end{tabular}

$\dagger+Z n+Z n, Z n$-supplemented diet throughout pregnancy; $-Z n+Z n, Z n$-deficient diet up to day 35 of pregnancy and then $\mathbf{Z n}$-supplemented diet until parturition; $-\mathbf{Z n}-\mathbf{Z n}$, $\mathbf{Z n}$-deficient diet throughout pregnancy; $+\mathrm{Zn}-\mathrm{Zn}, \mathrm{Zn}$-supplemented diet up to day 35 of pregnancy and then $\mathrm{Zn}$-deficient diet until parturition.

Mean values significantly different from those for $+Z n+Z n$ using Duncan's multiple range test: ${ }^{*} P<0.05$, ${ }^{* *} P<0.01$.

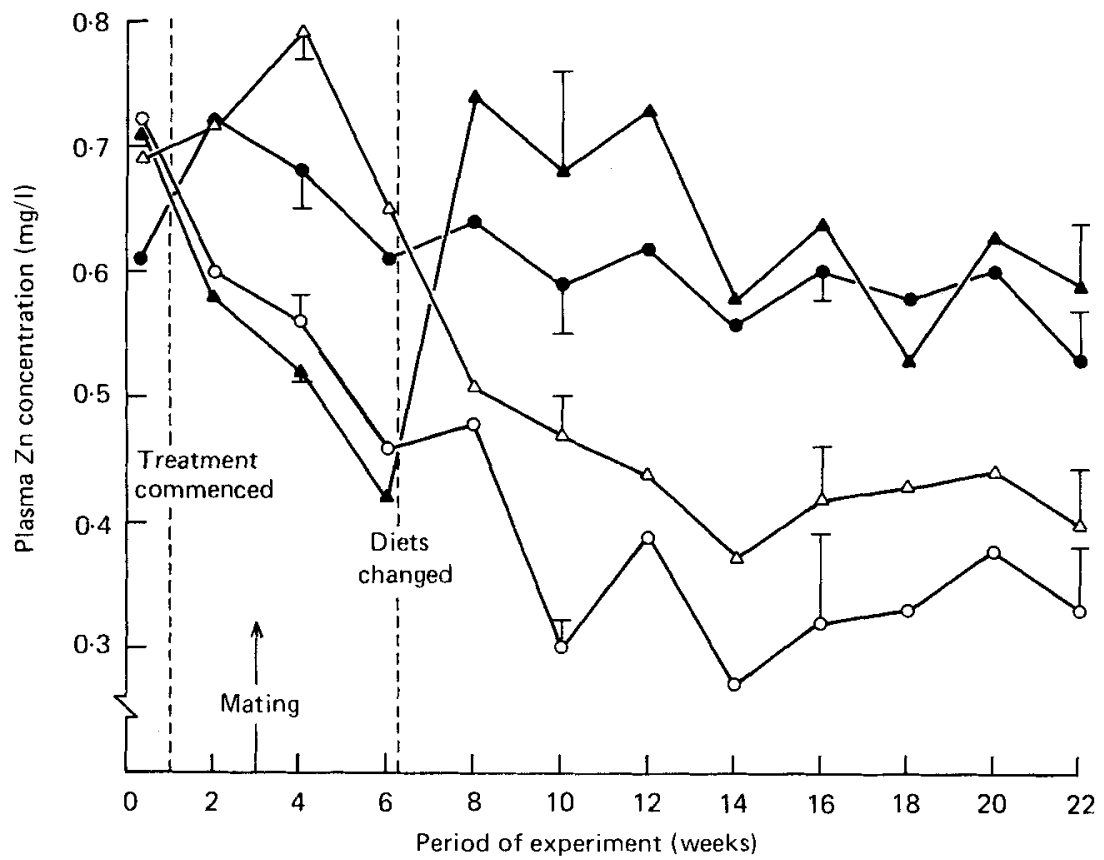

Fig. 1. Effect of dietary zinc intake on the concentration of $\mathrm{Zn}$ in plasma of pregnant ewes. (O), $+\mathrm{Zn}+\mathrm{Zn}, \mathrm{Zn}$-supplemented $(+\mathrm{Zn})$ diet throughout pregnancy; $(\mathbf{\Delta}),-\mathrm{Zn}+\mathrm{Zn}, \mathrm{Zn}$-deficient $(-\mathrm{Zn})$ diet up to day 35 of pregnancy and $+\mathrm{Zn}$ diet until parturition; $(\triangle),+\mathrm{Zn}-\mathrm{Zn}, \mathrm{Zn}$-supplemented $(+\mathrm{Zn})$ diet up to day 35 of pregnancy and $-\mathrm{Zn}$ diet until parturition; $(\mathrm{O}),-\mathrm{Zn}-\mathrm{Zn}, \mathrm{Zn}$-deficient $(-\mathrm{Zn})$ diet throughout pregnancy.

Ewes supplemented with $\mathrm{Zn}(+\mathrm{Zn}+\mathrm{Zn}$ and $-\mathrm{Zn}+\mathrm{Zn})$ produced heavier single-born lambs than $\mathrm{Zn}$-depleted ewes $(P<0 \cdot 05)$. The high- $\mathrm{Zn}$ lambs also had higher liver weights and more $\mathrm{Zn}$ in the liver, pancreas and whole carcass $(P<0.05)$ (Table 3), higher liver alkaline phosphatase activity $(P=0.05)$ and slightly higher activity of thymidine kinase in the thymus $(P=0 \cdot 07)$ than the low-Zn lambs (Table 4). A large variation within groups was also observed, particularly with respect to enzyme activities. 
Table 3. Effect of maternal zinc intake on the birth weight, organ weights, organ $\mathrm{Zn}$ content and organ $\mathrm{Zn}$ concentrations ( $\mathrm{mg} / \mathrm{kg}$ dry tissue) of the newborn lamb

(Mean values with their standard errors; no. of lambs in parentheses)

\begin{tabular}{|c|c|c|c|c|}
\hline \multirow[t]{2}{*}{ Group $^{\dagger} \ldots$} & \multicolumn{2}{|c|}{$\begin{array}{c}\text { High } \mathrm{Zn} \\
(+\mathrm{Zn}+\mathrm{Zn} \text { and }-\mathrm{Zn}-\mathrm{Zn})\end{array}$} & \multicolumn{2}{|c|}{$\begin{array}{c}\text { Low } Z n \\
(-Z n-Z n \text { and }+Z n-Z n)\end{array}$} \\
\hline & Mean & SE & Mean & SE \\
\hline Lamb wt $t^{\ddagger}(\mathrm{kg})$ & $4 \cdot 57$ & $0 \cdot 28(5)$ & $3 \cdot 81^{*}$ & $0 \cdot 17(5)$ \\
\hline Liver wt (g fresh wt) & $103 \cdot 0$ & $5 \cdot 33(5)$ & $67 \cdot 8^{* * *}$ & $4.33(5)$ \\
\hline Liver wt (\% birth wt) & 1.94 & $0 \cdot 10(9)$ & 1.75 & $0.08(11)$ \\
\hline Kidney wt $(\mathrm{g} \text { fresh } \mathrm{wt})^{\ddagger}$ & $10 \cdot 9$ & $0.44(5)$ & $10 \cdot 1$ & $0.66(5)$ \\
\hline Carcass $\mathrm{Zn}(\mathrm{mg})^{\ddagger}$ & $81 \cdot 8$ & $4 \cdot 4(5)$ & $62 \cdot 5^{*}$ & $5 \cdot 70(5)$ \\
\hline Carcass $\mathrm{Zn}(\mathrm{mg} / \mathrm{kg}) \S$ & $19 \cdot 3$ & $0.73(9)$ & $15 \cdot 4^{* *}$ & $0.80(11)$ \\
\hline Liver $\mathrm{Zn}(\mathrm{mg})$ & $2 \cdot 77$ & $0.19(9)$ & $1 \cdot 21^{* * *}$ & 0.30 (11) \\
\hline Liver $\mathrm{Zn}(\mathrm{mg} / \mathrm{kg})$ & $187 \cdot 7$ & $34-2(9)$ & $81.8^{*}$ & $16 \cdot 5(11)$ \\
\hline Kidney $\mathbf{Z n}(\mu \mathrm{g}) \ddagger$ & $113 \cdot 4$ & $6 \cdot 28(5)$ & $98 \cdot 6$ & $5 \cdot 73(5)$ \\
\hline Kidney $\mathrm{Zn}(\mathrm{mg} / \mathrm{kg})$ & $57 \cdot 6$ & $2.80(9)$ & $51 \cdot 5$ & $2.42(11)$ \\
\hline Thymus $\mathrm{Zn}(\mathrm{mg} / \mathrm{kg})$ & $89 \cdot 4$ & $8.72(9)$ & $78 \cdot 4$ & $2 \cdot 61(11)$ \\
\hline Pancreas $\mathrm{Zn}(\mathrm{mg} / \mathrm{kg})$ & $209 \cdot 3$ & $15 \cdot 2(9)$ & $132 \cdot 7^{*}$ & $14 \cdot 0(11)$ \\
\hline Plasma $\mathrm{Zn}(\mathrm{mg} / \mathrm{l})$ & 1.26 & $0 \cdot 14(9)$ & 1.00 & $0 \cdot 15(11)$ \\
\hline
\end{tabular}

$\dagger+Z n+Z n, Z n$-supplemented diet throughout pregnancy; $-Z n+Z n Z n$-deficient diet up to day 35 of pregnancy and then $\mathrm{Zn}$-supplemented diet until parturition; $-Z_{n}-\mathrm{Zn}$, $\mathrm{Zn}$-deficient diet throughout pregnancy; $+\mathrm{Zn}-\mathrm{Zn}, \mathrm{Zn}$-supplemented diet up to day 35 of pregnancy and then $\mathrm{Zn}$-deficient diet until parturition.

Mean values significantly different from those for high-Zn group using Student's $t$-test: ${ }^{*} P<0.05,{ }^{* *} P<0.01$, *** $P<0.001$.

\$Comparison between single lambs only, twins were excluded when they were significantly different from singles.

$\$$ Wet weight basis.

Table 4. Effect of maternal zinc intake on the activities of alkaline phosphatase (EC 3.1.3.1) and thymidine kinase (EC 2.7.1.21) in the newborn lamb

(Mean values with their standard errors; no. of lambs in parentheses)

\begin{tabular}{|c|c|c|c|c|c|}
\hline \multirow[t]{2}{*}{ Group $^{\dagger} \ldots$} & \multicolumn{2}{|c|}{$\begin{array}{c}\text { High } \mathbf{Z n} \\
(+\mathbf{Z n}+\mathbf{Z n} \text { and }-Z n+Z n)\end{array}$} & \multicolumn{2}{|c|}{$\begin{array}{c}\text { Low } Z n \\
(-Z n-Z n \text { and }+Z n-Z n)\end{array}$} & \multirow{2}{*}{$\begin{array}{c}\text { Statistical } \\
\text { significance } \\
\text { of difference } \\
\text { (Student's } \\
t \text { test) }\end{array}$} \\
\hline & Mean & $\mathrm{SE}$ & Mean & $\mathrm{SE}$ & \\
\hline \multicolumn{6}{|c|}{ Alkaline phosphatase $\ddagger$} \\
\hline Liver & $32 \cdot 2$ & $3.76(9)$ & $24 \cdot 8$ & $1.53(11)$ & $P=0.05$ \\
\hline Thymus & $113 \cdot 7$ & $8 \cdot 20(9)$ & $134 \cdot 3$ & $15 \cdot 70(11)$ & NS \\
\hline Plasma & $625 \cdot 7$ & 103.0 & $450 \cdot 9$ & 72.9 (11) & NS \\
\hline \multicolumn{6}{|c|}{ Thymidine kinase $e^{\S}$} \\
\hline Liver & 17.9 & $4 \cdot 5 \quad(9)$ & 15.5 & $1.25(11)$ & NS \\
\hline Thymus & $429 \cdot 9$ & $107 \cdot 2$ & 251.9 & $56 \cdot 1(11)$ & $P=0.07$ \\
\hline
\end{tabular}

$\dagger+\mathrm{Zn}+\mathrm{Zn}$, $\mathrm{Zn}$-supplemented diet throughout pregnancy; $-\mathrm{Zn}+\mathrm{Zn}, \mathrm{Zn}$-deficient diet up to day 35 of pregnancy and then $\mathrm{Zn}$-supplemented diet until parturition; $-\mathrm{Zn}-\mathrm{Zn}, \mathrm{Zn}$-deficient diet throughout pregnancy; $+\mathrm{Zn}-\mathrm{Zn}, \mathrm{Zn}$-supplemented diet up to day 35 of pregnancy and then $\mathrm{Zn}$-deficient diet until parturition.

$\$$ Liver and thymus in $\mathrm{mU} / \mathrm{mg}$ protein, plasma in $\mathrm{mU} / \mathrm{l}$. One unit is the enzyme activity that causes $1 \mu \mathrm{mol}$ substrate to react in $1 \mathrm{~min}$ at $25^{\circ}$.

$\S$ pmol [ $\left.{ }^{3} \mathrm{H}\right]$ thymidine incorporated into thymidine monophosphate/h per $\mathrm{mg}$ protein.

NS, not significant. 


\section{DISCUSSION}

The $\mathrm{Zn}$-deficient ewes had significantly reduced feed intakes and slightly reduced live weights compared with the ewes that were supplemented with $\mathrm{Zn}$ throughout pregnancy. No other external signs of $\mathrm{Zn}$ deficiency were noted, no sheep developed parakeratosis and the heavy salivation reported when egg-white is used as a dietary protein source (Underwood \& Somers, 1969; Apgar \& Travis, 1979) did not occur. Therefore, although the ewes had low $\mathrm{Zn}$ intakes with associated reduced plasma $\mathrm{Zn}$ concentrations and inappetence, no obvious external signs of $\mathrm{Zn}$ deficiency existed. In grazing ruminants, this lack of external lesions means that $\mathrm{Zn}$ deficiency could easily pass undetected. That such $\mathrm{Zn}$ responsive situations may occur has been previously demonstrated (Masters \& Fels, 1980; Mayland et al. 1980). The decline in food intake is a well documented characteristic of $\mathrm{Zn}$ deficiency (Underwood, 1977). The $\mathrm{Zn}$-deficient ewes consumed $25 \%$ less dry matter than those given $\mathrm{Zn}$ throughout pregnancy. Unlike other experiments with other animal species (Mills et al. 1969) and sheep (Underwood \& Somers, 1969) however, the $-\mathrm{Zn}+\mathrm{Zn}$ group did not increase feed consumption when repleted with $\mathrm{Zn}$ despite rapid increases in plasma $\mathrm{Zn}$ concentration. Although there is no apparent reason for this, it may be related to the dry and dusty nature of the diet. Repletion with $\mathrm{Zn}$ may not have sufficiently increased the palatability of the diet.

$\mathrm{Zn}$ content of the diet did not significantly influence the ability of ewes to become pregnant or maintain pregnancy. There was no evidence indicating that $\mathrm{Zn}$ deficiency, which has been shown to cause dystocia in rats (Apgar, 1968) has a similar effect in ewes. Feeding the $\mathrm{Zn}$-deficient diet to ewes resulted in decreased lamb birth weights. This may be a direct result of $\mathrm{Zn}$ deficiency per se, an indirect effect associated with decreased food intake of the ewes or a combination of both. Reduced birth weights resulting from $\mathrm{Zn}$ deficiency have been reported in rats (Williams et al. 1973; Hurley \& Cosens, 1974) and grazing sheep (Masters \& Fels, 1980) but not peviously with penned sheep (Apgar \& Travis, 1979). Apgar \& Travis (1979) induced $\mathrm{Zn}$ deficiency in penned sheep during the last third of pregnancy. In the current experiment $\mathrm{Zn}$ deficiency was initiated either before mating or during the first third of gestation. This difference in the length of deficiency may be responsible for the different results. Reduced lamb birth weights caused by decreased maternal food intake have also been reported previously (Schinckel, 1963). In the current experiment it is possible that the reduced intake by $\mathrm{Zn}$-deficient ewes may have contributed to reduced lamb birth weights.

The mean total amount of $\mathrm{Zn}$ accumulated in each single-born lamb was 81.8 and $62.5 \mathrm{mg}$ for the high- and low-Zn lambs respectively. In comparison, 140-d-old twin, triplet or quadruplet foetuses not deprived of $\mathrm{Zn}$ have been reported to contain $68-81 \mathrm{mg} \mathrm{Zn}$ (Hansard \& Mohammed, 1968; Williams et al. 1978). Another report (Williams \& Bremner, 1976 ) indicated that at least $85 \%$ of the total foetal $\mathrm{Zn}$ burden is accumulated after day 80 of gestation and that on day 80 the foetus contains only 7-8 $\mathrm{mg}$ of $\mathrm{Zn}$. If this rate of accumulation is applied to the current results then the high- $\mathrm{Zn}$ foetus accrued approximately $74 \mathrm{mg} \mathrm{Zn}$ or between 2 and $4 \%$ of total maternal intake, and the low- $\mathrm{Zn}$ foetus $55 \mathrm{mg}$ or approximately $35 \%$ of total maternal $\mathrm{Zn}$ intake between days 80 and 150 .

It is well established that the efficiency of $\mathrm{Zn}$ absorption in rats increases during $\mathrm{Zn}$ deficiency (Davies \& Williams, 1977). There is also evidence in cattle and sheep that $\mathrm{Zn}$ status/intake affects $\mathrm{Zn}$ absorption (Kirchgessner et al. 1978, Suttle et al. 1982). The results of this current experiment indicate that a combination of $\mathrm{Zn}$ deficiency and pregnancy in the ewe leads to highly efficient utilization of ingested $\mathrm{Zn}$. The $\mathrm{Zn}$-deficient ewes consumed daily $0.57 \mathrm{~kg}$ of a diet containing $4 \mathrm{mg} \mathrm{Zn} / \mathrm{kg}$, and total $\mathrm{Zn}$ intake was therefore approximately $2.3 \mathrm{mg} / \mathrm{d}$. If $\mathrm{Zn}$ absorption was as low as $13 \%$ (Hansard \& Mohammed, 1968) then the $\mathrm{Zn}$-deficient ewes would have utilized only $0.3 \mathrm{mg} \mathrm{Zn} / \mathrm{d}$ from the diet. This 
would probably not be sufficient for even the maintenance requirement of a non-pregnant ewe and, as the $\mathrm{Zn}$-deficient ewes deposited an average of $0.80 \mathrm{mg} \mathrm{Zn} / \mathrm{d}$ into the single foetuses during the last $70 \mathrm{~d}$ of gestation, absorption must have been greatly enhanced during this period.

Even with complete absorption and retention of the $2.3 \mathrm{mg} \mathrm{Zn}$ ingested daily it is difficult to see how the demands of pregnancy were met. During this last half of pregnancy no skin lesions or other visible signs of deficiency appeared and plasma $\mathrm{Zn}$ levels did not fall to the extremely low levels reported in previous experiments (Mills et al. 1967; Masters \& Moir, 1980). The only source of $\mathrm{Zn}$ available to the ewes other than that coming directly from the diet was $\mathrm{Zn}$ mobilized during tissue breakdown. All the ewes in the $+\mathrm{Zn}-\mathrm{Zn}$ and $-Z n-Z n$ groups had a net body-weight loss and catabolism of tissue such as muscle would mobilize $\mathrm{Zn}$. For example, the $-\mathrm{Zn}-\mathrm{Zn}$ ewes had a mean weight loss of $0.9 \mathrm{~kg}$ and, during this time, the ewe produced a $3.8 \mathrm{~kg}$ lamb accompanied by approximately $1.5 \mathrm{~kg}$ fluids and membranes (Schinckel, 1963). The total loss of body-weight by the ewe was then $6.2 \mathrm{~kg}$. As muscle contains approximately $24 \mathrm{mg}(\mathrm{Zn} / \mathrm{kg}$ (Suttle, 1979), then the total amount of $\mathrm{Zn}$ mobilized may be as much as $150 \mathrm{mg}$. Although this may be an overestimate due to some of the weight loss being fat and containing less $\mathrm{Zn}$, the amount of $\mathrm{Zn}$ mobilized by tissue catabolism is still substantial. It is reasonable to assume that this $\mathrm{Zn}$ is utilized by the ewe and deposited in the foetus.

This release and utilization of large amounts of $\mathrm{Zn}$ from tissues by the ewe is not normally found in the rat (Hurley \& Swenerton, 1971) but is apparent in that animal when tissue or bone catabolism is induced by a concurrent $\mathrm{Zn}$ and protein or $\mathrm{Zn}$ and calcium deficiency (Hurley \& Tao, 1972; Hurley et al. 1973). This difference between species may be related to the size of the concepta in proportion to the adult animal and the length of gestation (Apgar et al. 1981). The ewe produces a foetus approximately $10 \%$ of its own weight in $150 \mathrm{~d}$ compared with the rat that produces a litter approximately $25-30 \%$ of its own weight in $22 \mathrm{~d}$. The current experiment shows that the ewe may have a total weight loss exceeding the size of the foetus by $50 \%$ and still maintain pregnancy and produce a lamb. A comparable weight loss in the rat would be $40-45 \%$ of total body-weight, this would have severe consequences on health and survival. The ewes were mature and had no $\mathrm{Zn}$ requirement for growth. A younger growing ewe with a higher total $\mathrm{Zn}$ requirement may be less able to provide $\mathrm{Zn}$ by tissue catabolism and therefore may become more severely $\mathrm{Zn}$ deficient.

$\mathrm{Zn}$ concentrations in the liver and pancreas of the lambs as well as the whole carcass were significantly reduced by the low-Zn diet. Liver of high- $\mathrm{Zn}$ lambs contained a total of $2.8 \mathrm{mg}$ $\mathrm{Zn}$ and those of the low-Zn lambs $1.2 \mathrm{mg}$. These levels are equivalent to 3.4 and $1.9 \%$ of total carcass $\mathrm{Zn}$ in the high- and low- $\mathrm{Zn}$ lambs respectively. This is less than the $5 \cdot 6-8 \cdot 8$ $\mathrm{mg} \mathrm{Zn}$ found in the livers of 140-d-old foetuses by other workers (Hansard \& Mohammed, 1968; Williams et al. 1978). It is evident from the current experiment that lambs from $\mathrm{Zn}$-depleted ewes have very small stores of $\mathrm{Zn}$ in the liver and even lambs from $\mathrm{Zn}$-supplemented ewes do not have a substantial store.

Maternal $\mathrm{Zn}$ deficiency affected some enzymatic activities as well as tissue $\mathrm{Zn}$ concentrations. Alkaline phosphatase was reduced by $23 \%$ in the liver and thymidine kinase by $41 \%$ in the thymus of $\mathrm{Zn}$-deprived lambs. It should be mentioned that alkaline phosphatase activity and thymic growth may be influenced by inanition as well as $\mathrm{Zn}$ deficiency (Luecke et al. 1968, 1978). Therefore, these changes may be related to feed consumption of the ewes. However, the decline in feed intake by the $\mathrm{Zn}$-depleted ewes occurred as a direct result of $\mathrm{Zn}$ deficiency and therefore the responses observed are a consequence of reduced $\mathrm{Zn}$ intake. In grazing sheep both the direct and indirect effects of $\mathrm{Zn}$ deficiency may severely disrupt production and reproduction. 
The authors wish to thank Mr P. Moore, Mr M. Weeks and Mr R. Armstrong for technical assistance and the Australian Wool Corporation for financial support.

\section{REFERENCES}

Apgar, J. (1968). Am. J. Physiol. 215, 160.

Apgar, J., House, W. A. \& Welch, R. M. (1981). In Trace Element Metabolism In Man and Animals, vol. 4, p. 268. [J. McC. Howell, J. M. Gawthorne and C. L. White, editors]. Canberra: Australian Academy of Science. Apgar, J. \& Travis, H. F. (1979). J. Anim. Sci. 48, 1234.

Davies, N. T. \& Williams, R. B. (1977). Br. J. Nutr. 38, 417.

Duncan, J. R. \& Hurley, L. S. (1978). Proc. Soc. exp. Biol. Med. 159, 39.

Egan, A. R. (1972). Aust. J. exp. Agric. Anim. Husb. 12, 131.

Hansard, S. L. \& Mohammed, A. S. (1968). J. Anim. Sci. 27, 807.

Hurley, L. S. \& Cosens, G. (1974). In Trace Element Metabolism in Animals, vol. 2, p. 516. [W. G. Hoekstra, J. W. Suttie, H. E. Ganther and W. Mertz, editors]. Baltimore: University Park Press.

Hurley, L. S., Sucher, K., Story, D. \& Cosens, G. (1973). J. Nutr. 103, xxv.

Hurley, L. S. \& Swenerton, H. (1966). Proc. Soc. exp. Biol. Med. 123, 692.

Hurley, L. S. \& Swenerton, H. (1971). J. Nutr. 107, 597.

Hurley, L. S. \& Tao, S. (1972). Am. J. Physiol. 222, 322.

Kirchgessner, M., Schwarz, W. A. \& Roth, H. P. (1978). In Trace Element Metabolism in Man and Animals, vol. 3, p. 116[M. Kirchgessner, editor]. Freising-Weihenstephan: Institut fur Ernahrungsphysiologie, Technische Universitat Munchen.

Lowry, O. H., Roseborough, N. J., Farr, A. L. \& Randall, R. J. (1951). J. biol. Chem. 193, 265.

Luecke, R. W., Olman, M. E. \& Baltzer, B. V. (1968). J. Nutr. 94, 344.

Luecke, R. W., Simonel, C. E. \& Fraker, P. J. (1978). J. Nutr. 108, 881.

Masters, D. G. (1981). In Trace Element Metabolism in Man and Animals, vol. 4, p. 331 [J. McC. Howell, J. W. Gawthorne and C. L. White, editors]. Canberra: Australian Academy of Science.

Masters, D. G. \& Fels, H. (1980). Biol. Trace Element Res. 2, 281.

Masters, D. G. \& Moir, R. J. (1980). Aust. J. exp. Agric. Anim. Husb. 20, 547.

Mayland, H. F., Rosenau, R. C. \& Florence, A. R. (1980). J. Anim. Sci. 51, 966.

Mills, C. F., Dalgarno, A. C., Williams, R. B. \& Quarterman, J. (1967). Br. J. Nutr. 21, 751.

Mills, C. F., Quarterman, J., Chesters, J. K., Williams, R. B. \& Dalgarno, A. L. (1969). Am. J. Clin. Nutr. 22 , 1240.

Sawyer, G. J. (1978). The influence of high temperatures on reproduction in the Merino ewe. PhD Thesis, University of Western Australia.

Schinckel, P. G. (1963). Wld. Conf. Anim. Prod., vol. 1, p. 199. Rome: European Association for Animal Production.

Short, R. V. (1972). In Reproduction in Mammals, vol. 3, p. 42 [C. R. Austin and R. V. Short, editors]. London: Cambridge University Press.

Suttle, N. F. (1979). Br. J. Nutr. 42, 89.

Suttle, N. F., Lloyd Davies, H. \& Field, A. C. (1982). Br. J. Nutr. 47, 105.

Underwood, E. J. (1977). Trace Elements in Human and Animal Nutrition, 4th ed., p. 196. London and New York: Academic Press.

Underwood, E. J. \& Somers, M. (1969). Aust. J. agric. Res. 20, 889.

Williams, R. B. \& Bremner, I. (1976). Proc. Nutr. Soc. 35, 86A, 87A, 88A.

Williams, R. B., Demertzis, P. \& Mills, C. F. (1973). Proc. Nutr. Soc. 32, 3A.

Williams, R. B., McDonald, I. \& Bremner, I, (1978). Br. J. Nutr. 40, 377.

Witschi, H. P. (1970). Biochem. J. 120, 623. 